\title{
Optimasi Formula Tahu Lembut Instan dan Rasio Air Rehidrasi dalam Pengembangan Wedang Tahu sebagai Pangan Fungsional
}

\section{Optimation of Instant Soft Tofu's Formula and Rehydration Ratio on Development of Soft Tofu Dessert as a Functional Food}

\author{
Nurheni Sri Palupi ${ }^{1,2)^{*}}$, Nida Raihana Zhafira ${ }^{1)}$, Budi Nurtama ${ }^{1)}$ \\ ${ }^{1)}$ Departemen Ilmu dan Teknologi Pangan, Fakultas Teknologi Pertanian, Institut Pertanian Bogor, Bogor \\ ${ }^{2)}$ Southeast Asian Food and Agricultural Science and Technology Center, LPPM, Institut Pertanian Bogor, Bogor
}

\begin{abstract}
Soft tofu dessert is a traditional food which is known due to its health benefits. Nowadays, people are not only considering the health benefits of food but also its practicality and shelf life. The development of instant soft tofu dessert is expected for solving the problem. Instant soft tofu dessert is a mix of instant soft tofu and ginger drink. The objective of this study was to obtain the optimum formula and rehydration ratio of instant soft tofu, identify the sensory, chemical, physical characteristics of instant soft tofu dessert, and determine the antioxidant activity of instant soft tofu dessert. Optimization of instant soft tofu's formula and rehydration process was conducted by using Response Surface Methodology (RSM) with the variables were the concentration of soymilk powder, carrageenan, and volume of water. Responses that was measured were hardness, gummine ss and chewiness. The result of optimal formula and rehydration process consisted of 93.2\% soybean powder, $6.8 \%$ carrageenan and water volume ratio was 1:8. The hardness of optimal soft tofu was $154.60 \mathrm{gf}$, gumminess was $28.53 \mathrm{gf}$, and chewiness was $16.16 \mathrm{gf}$. Consumption of soft tofu dessert in $38 \mathrm{~g}$ serving size generated energy $175.78 \mathrm{kkal}, 19.55 \%$ AKG of protein, $9.52 \%$ AKG of fat, and $5.50 \%$ AKG of carbohydrate. The antioxidant activity of instant soft tofu dessert was 16.16 ppm AEAC (ascorbic acid equivalent antioxidant capacity). The result of sensory test of color, flavour, texture, and overall attributes showed that the panelist preference for instant soft tofu dessert is higher than the traditional soft tofu dessert significantly $(p<0.05)$.
\end{abstract}

Keywords: carrageenan, instant soft tofu dessert, rehydration, response surface method, soft tofu

\begin{abstract}
Abstrak. Wedang tahu merupakan pangan tradisional yang dikenal bermanfaat bagi kesehatan. Pada saat ini produk pangan yang dikehendaki masyarakat tidak hanya mempertimbangkan manfaatnya bagi kesehatan, akan tetapi juga kepraktisan dan keawetannya. Hal ini mendorong dikembangkannya produk wedang tahu instan. Produk wedang tahu instan terdiri atas serbuk tahu lembut instan dan kuah jahe instan. Penelitian ini bertujuan memperoleh formula dan rasio air rehidrasi optimum tahu lembut instan, mengidentifikasi karakteristik sensori, kimia dan fisik wedang tahu instan, serta menguji nilai aktivitas antioksidan wedang tahu instan. Optimasi formula dan proses rehidrasi tahu lembut instan dilakukan menggunakan metode Response Surface Methodology (RSM) dengan variabel bebas berupa konsentrasi sari kedelai, karaginan dan rasio volume air. Respon yang diukur yaitu profil tekstur kekerasan, kelengketan, dan daya kunyah. Formula dan proses rehidrasi optimal yang direkomendasikan yaitu kombinasi sari kedelai $93.2 \%$, karaginan $6.8 \%$, dan rasio volume serbuk:air 1:8. Formula tersebut menghasilkan nilai kekerasan sebesar 154.60 gf, kelengketan sebesar 28.53 gf dan daya kunyah sebesar 16.16 gf. Konsumsi wedang tahu instan dengan takaran saji $38 \mathrm{~g}$ dapat menghasilkan energi sebesar 175.78 kkal, protein $19.55 \%$ AKG, lemak 9.52\% AKG, dan karbohidrat 5.50\% AKG. Wedang tahu instan menghasilkan aktivitas antioksidan sebesar $16.16 \mathrm{ppm}$ AEAC. Hasil analisis sensori menunjukkan bahwa atribut warna, rasa, tekstur dan keseluruhan wedang tahu instan lebih disukai panelis dibandingkan wedang tahu tradisional secara signifikan $(\mathrm{p}<0.05)$.
\end{abstract}

Kata Kunci: karaginan, rehidrasi, response surface method, tahu lembut, wedang tahu instan

\footnotetext{
Aplikasi Praktis: Hasil penelitian ini memberikan informasi mengenai pengembangan produk tradisional menjadi produk instan yang praktis. Pembuatan wedang tahu instan merupakan salah satu strategi untuk memberi nilai tambah pada pangan tradisional yang diketahui bermanfaat untuk kesehatan. Penelitian ini juga menghasilkan kombinasi formula bahan baku dan proses rehidrasi optimal wedang tahu instan sebagai acuan untuk pengembangan skala industri.
} 


\section{PENDAHULUAN}

Kedelai merupakan salah satu bahan pangan dengan nilai kandungan protein yang tinggi. Kadar protein pada kedelai termasuk yang paling tinggi dibandingkan sumber pangan nabati lainnya yaitu mencapai $40 \%$ (Winarsi 2010). Kedelai mengandung beberapa asam amino esensial yang diperlukan oleh tubuh serta komponen bioaktif isoflavon yang diketahui memiliki sifat antioksidan. Potensi kandungan gizi pada kedelai, terutama kandungan proteinnya yang tinggi menjadikan kedelai termasuk bahan baku olahan produk pangan yang bermanfaat. Salah satu produk olahan kedelai yang bermanfaat bagi kesehatan dan digemari masyarakat Indonesia adalah wedang tahu.

Wedang tahu merupakan pangan tradisional yang terdiri atas kombinasi tahu lembut dan kuah jahe. Tahu lembut pada wedang tahu berasal dari koagulasi sari kedelai secara utuh tanpa mengalami proses pengepresan sehingga memiliki tekstur seperti puding (Mullin et al. 2001). Kuah jahe pada wedang tahu memiliki karakter menyerupai sari jahe secara umum, namun diberi penambahan gula merah sehingga memiliki warna coklat pekat dengan intensitas kemanisan yang lebih tinggi. Kuah jahe sebagai salah satu komponen wedang tahu juga bermanfaat bagi kesehatan. Jahe merupakan salah satu jenis rempah yang memiliki aktivitas antioksidan yang tinggi. Hal ini dipengaruhi oleh tingginya total fenol yang terkandung dalam jahe (Stoilova et al. 2007)

Pada saat ini produk pangan yang dikehendaki oleh masyarakat tidak hanya mempertimbangkan unsur pemenuhan gizi dan manfaatnya bagi kesehatan, akan tetapi juga harus praktis, cepat saji, dan mudah disimpan. Oleh karena itu, kecenderungan konsumen saat ini mengarah pada produk yang menonjolkan sifat instan. Hal ini menjadi peluang yang sangat potensial bagi perkembangan produk pangan berbentuk instan dengan menggunakan bahan baku yang bernilai gizi tinggi. Salah satunya yaitu produk wedang tahu instan.

Produk wedang tahu instan terdiri atas serbuk tahu lembut instan dan kuah jahe instan. Tahu lembut instan dibuat dari pencampuran antara sari kedelai yang dikeringkan menggunakan teknik spray drying dengan karaginan hasil ekstraksi rumput laut Euchema cottonii (Campo et al. 2009). Karaginan dapat berinteraksi dengan protein sari kedelai membentuk ikatan kovalen sehingga menghasilkan pengaruh berupa pembentukan gel pada tahu lembut (Winarno 2008). Pembuatan kuah jahe instan menggunakan metode kokristalisasi. Metode ini didasarkan pada pemanfaatan sifat gula pasir yang ditambahkan pada ekstrak jahe, yaitu dapat kembali membentuk kristal setelah dicairkan.

Pada pembuatan wedang tahu instan, belum diketahui rasio antara serbuk sari kedelai dan serbuk karagenan yang optimal, demikian juga dengan rasio antara serbuk tahu lembut instan dengan volume air

Korespondensi: hnpalupi@yahoo.com yang digunakan dalam proses rehidrasi. Oleh karena itu, pada penelitian ini akan dilakukan optimasi formula dan proses rehidrasi dari keduanya. Penelitian ini difokuskan untuk memperoleh formula dan proses rehidrasi optimal dari tahu lembut instan berdasarkan respon profil tekstur yang diharapkan. Penentuan formula optimal kuah jahe instan berdasarkan penelitian terpisah, sedangkan proses rehidrasi mengikuti rehidrasi jahe instan komersial.

Penelitian ini bertujuan memperoleh formula (rasio antara serbuk sari kedelai dan serbuk karagenan) dan proses rehidrasi optimum tahu lembut instan, memperoleh karakteristik sensori, kimia, nilai gizi dan fisik, serta memperoleh data ilmiah kandungan aktivitas antioksidan wedang tahu instan. Penelitian ini diharapkan dapat memberi nilai tambah pada pangan tradisional wedang tahu menjadi produk wedang tahu instan yang awet dan mudah disajikan.

\section{BAHAN DAN METODE}

\section{Bahan dan alat}

Bahan yang digunakan pada penelitian ini adalah kacang kedelai non $G M O$ varietas Amerika Serikat yang diperoleh dari Rumah Tempe Indonesia, karaginan hasil ekstraksi Euchema cottonii yang diperoleh dari CV. Nura Jaya kota Surabaya, jahe emprit varietas Halina dan jahe merah varietas Jahira yang diperoleh dari BALITTRO, gula pasir "Gulaku", gula merah "Cap Semut", krimer nabati "Max Creamer", wedang tahu tradisional yang diperoleh dari pedagang di Jalan Surya Kencana Bogor, serta bahan-bahan kimia yang digunakan pada analisis proksimat (heksana, $\mathrm{HCl}, \mathrm{H}_{2} \mathrm{SO} 4$, $\mathrm{HgO}, \mathrm{K}_{2} \mathrm{SO}_{4}, \mathrm{NaOH}$, dan $\mathrm{H}_{2} \mathrm{BO}_{3}$ ) dan aktivitas antioksidan (DPPH, asam askorbat, dan etanol).

Alat yang digunakan pada penelitian ini, antara lain peralatan pembuatan tahu lembut instan, peralatan pembuatan kuah jahe instan, mini spray dryer Buchi B290, TA-XT2i Texture Analyzer produksi Texture Analyzer Corp. New York, termometer raksa, oven pengering WTB Binder Germany, tanur listrik Thermolyn 47900, alat ekstraksi Soxhlet, alat analisis Kjeldahl, spektrofotometri UV-Vis spectronic 20, serta alat-alat gelas.

\section{Pelaksanaan penelitian}

Penelitian ini terbagi menjadi enam tahap. Tahap pertama adalah pembuatan wedang tahu instan yang terdiri atas pembuatan serbuk tahu lembut instan dan serbuk kuah jahe instan. Tahap kedua adalah optimasi formula dan proses rehidrasi tahu lembut instan menggunakan Response Surface Methodology (RSM). Tahaptahap selanjutnya yaitu karakterisasi sensori, kimia, nilai gizi, fisik dan pengujian aktivitas antioksidan wedang tahu instan.

Pembuatan tahu lembut instan. Pembuatan tahu lembut instan didasarkan pada pembuatan tahu lembut secara tradisional (Indrastuti 2015) yang dimodifikasi menggunakan karaginan dan sari kedelai bubuk yang 
dikeringkan dengan teknik spray drying. Pembuatan sari bubuk kedelai diawali dengan tahap pencucian kacang kedelai kemudian perendaman dengan perbandingan air:kedelai sebesar 3:1 pada suhu ruang selama 9 jam. Kedelai kemudian dipisahkan dari kulitnya dan digiling menggunakan blender dengan penambahan air:kedelai sebesar 4:1. Slurry yang diperoleh disaring dan dipisahkan dari ampas. sari kedelai kemudian dipanaskan pada suhu $90^{\circ} \mathrm{C}$ selama 5 menit sambil terus diaduk. Sari kedelai yang telah diturunkan suhunya kemudian dikeringkan dengan menggunakan spray dryer pada suhu inlet $185^{\circ} \mathrm{C}$ dan suhu outlet $82^{\circ} \mathrm{C}$ hingga terbentuk sari bubuk kedelai. Sari bubuk kedelai kemudian dicampurkan secara kering dengan karaginan pada konsentrasi tertentu yang akan dioptimasi dan krimer nabati 5\% (b/b). Konsentrasi krimer mengikuti konsentrasi penggunaan krimer pada puding instan komersial. Campuran serbuk tahu lembut instan kemudian diayak dengan ayakan berukuran 100 mesh sehingga ukurannya seragam.

Pembuatan kuah jahe instan. Proses pembuatan kuah jahe instan pada penelitian ini didasarkan pada metode pembuatan serbuk jahe instan (Rifkowaty dan Martanto 2016) dengan teknik kristalisasi. Formula yang digunakan pada penelitian ini didasarkan pada formula optimal yang diperoleh pada penelitian sebelumnya (Wardiani 2015), yaitu kombinasi jahe merah 50\% dan jahe emprit 50\%. Pembuatan kuah jahe instan diawali dengan tahapan pencucian, penimbangan jahe, gula pasir, dan gula merah. Jahe selanjutnya diparut dan disaring hingga diperoleh filtrat jahe. Filtrat diberi penambahan gula pasir dengan perbandingan 1:1 serta diberi penambahan gula merah sebanyak $10 \%$ (b/b), kemudian dipanaskan hingga mendidih. Campuran dilakukan pengadukan cepat hingga terbentuk kristal lalu diayak dengan ayakan berukuran 40 mesh sehingga dihasilkan serbuk kuah jahe instan dengan ukuran seragam.

Optimasi formula dan proses rehidrasi tahu lembut instan. Rancangan dan optimasi pada penelitian ini menggunakan metode Response Surface Methodology (RSM) dengan rancangan Combined D-Optimal. Pembuatan rancangan formulasi dan respon pengujian dilakukan dengan menggunakan program Design Expert 7.0 (DX7). Penelitian diawali dengan pemilihan variabel bebas pada pengolahan tahu lembut instan yang berpengaruh terhadap respon yang dioptimasi, yaitu profil tekstur. Profil tekstur (kekerasan, kelengketan, dan daya kunyah) dipilih sebagai respon karena dapat sangat memengaruhi penerimaan konsumen terhadap produk yang memiliki rasa hambar seperti tahu lembut (Kao et al. 2003). Variabel bebas yang digunakan untuk memperoleh formula optimal yaitu konsentrasi sari kedelai dan koagulan karaginan. Menurut Indrastuti (2015), kenaikan konsentrasi koagulan dapat menyebabkan peningkatan profil teksur tahu lembut. Variabel bebas yang digunakan untuk memperoleh proses rehidrasi optimal yaitu rasio volume air yang ditambahkan pada serbuk wedang tahu instan. Rasio volume air yang ditambahkan pada proses rehidrasi dapat memengaruhi profil tekstur produk akhir terutama profil kekerasan.

Penentuan batas minimum dan maksimum variabel bebas untuk optimasi dilakukan berdasarkan penelitian sebelumnya (Indrastuti 2015) dan berdasarkan hasil trial error yang dilakukan. Nilai yang digunakan untuk konsentrasi sari kedelai (\%) berkisar antara 90 sampai 96. Konsentrasi sari kedelai di bawah $90 \%$ tekstur tahu yang terbentuk terlalu lunak sedangkan konsentrasi di atas $96 \%$ tekstur tahu yang terbentuk terlalu keras serta warna terlalu kuning. Konsentrasi karaginan (\%) yang digunakan sebagai penggumpal berkisar antara 4 sampai 10. Konsentrasi karaginan di bawah $4 \%$ curd pada tahu lembut yang terbentuk belum sempurna, sedangkan konsentrasi di atas $10 \%$ tahu lembut yang terbentuk terlalu keras. Batas minimum dan maksimum rasio volume air yang digunakan untuk rehidrasi tahu lembut instan yaitu rasio serbuk tahu lembut : air berkisar antara 1:8 sampai 1:4. Rasio serbuk tahu lembut : air dibawah $1: 8$, tekstur tahu yang terbentuk terlalu lembek sedangkan pada rasio di atas 1:4 tekstur tahu yang terbentuk sangat keras.

Optimasi dilakukan untuk memperoleh formula dan proses optimal dengan nilai prediksi variabel respon yang paling seusai dengan nilai yang diinginkan (Cornell 2011). Formula optimal ditentukan berdasarkan formula dengan nilai desirability maksimum yaitu mendekati nilai 1.0. Kombinasi formula dan proses rehidrasi optimum yang diperoleh kemudian diverifikasi dengan mengukur profil tekstur tahu lembut instan sehingga menghasilkan variabel respon yang sebenarnya. Hasil yang diperoleh kemudian dibandingkan dengan nilai variabel respon yang diprediksi oleh RSM sehingga dapat dilihat kesesuaiannya.

Pengukuran profil tekstur dilakukan setelah proses rehidrasi tahu lembut instan sesuai dengan formula dan proses terpilih dengan metode texture profile analysis (TPA). Metode TPA dipilih karena dapat mensimulasikan proses pengunyahan pada indera manusia dengan memberikan gaya tekan terhadap produk sebanyak dua kali. Profil tekstur diukur menggunakan alat TA-XT2i Texture Analyzer. Probe yang digunakan adalah bentuk cylindrical dengan diameter $35 \mathrm{~mm}$, serta diatur pada pre test speed $2 \mathrm{~mm} / \mathrm{s}$, test speed $1 \mathrm{~mm} / \mathrm{s}$, post test speed $2 \mathrm{~mm} / \mathrm{s}$, distance $50 \%$, time $5 \mathrm{~s}$, dan count 2 (Obatolu 2007). Respon yang digunakan yaitu nilai kekerasan (hardness), kelengketan (gumminess), dan daya kunyah (chewiness). Kekerasan ditentukan dari nilai puncak pada tekanan pertama. Kelengketan dihitung dari hasil perkalian antara kekerasan dan nilai daya kohesif yang diperoleh dari perhitungan. Daya kunyah dihitung dari hasil perkalian antara kelengketan dan nilai elastisitas yang diperoleh dari perhitungan (Andarwulan et al. 2011).

Penetapan target respon didasarkan pada pengamatan visual produk akhir tahu lembut yang dikorelasikan dengan hasil pengukuran tekstur menggunakan Texture Analyzer. Kekerasan ditetapkan in 
range yaitu 120.00-180.00 gf dengan skala kepentingan 3 . Nilai tersebut disesuaikan dengan kriteria tahu lembut pada penelitian sebelumnya (Indrastuti 2015) yang telah disukai konsumen melalui uji organoleptik. Kelengketan ditetapkan in range yaitu 29.00-79.00 gf dengan skala kepentingan 3. Daya kunyah ditetapkan in range yaitu 10.00-18.00 gf dengan skala kepentingan 3. Tahu lembut dengan nilai daya kunyah dibawah 10.00 gf memiliki tekstur yang terlalu lembek dan mudah hancur, sedangkan tahu lembut dengan daya kunyah diatas 18.00 gf memiliki tekstur yang terlalu keras.

Karakterisasi sensori wedang tahu instan. Karakterisasi sensori dilakukan untuk mengetahui tingkat kesukaan terhadap produk wedang tahu instan disbandingkan dengan wedang tahu tradisional. Panelis yang digunakan pada penelitian ini yaitu 70 orang panelis tidak terlatih di lingkungan Kampus IPB Bogor. Karakterisasi sensori dilakukan dengan metode rating hedonik (BSN 2006) No SNI 01-2346-2006. Karakteristik yang dianalisis berupa warna, rasa, aroma, tekstur, dan keseluruhan. Penilaian berupa skala hedonik dengan rentang 1 (sangat tidak suka) sampai dengan 7 (sangat suka). Data kesukaan atribut antar sampel masingmasing panelis kemudian dianalisis dengan uji Independent T-test menggunakan program SPSS 20.

Karakterisasi kimia dan nilai gizi wedang tahu instan. Karakteristisasi kimia wedang tahu instan dilakukan dengan analisis kadar air metode oven (AOAC 2012), kadar abu metode pengabuan kering (AOAC 2012), kadar lemak metode soxhlet (AOAC 2012), kadar protein metode kjeldahl (AOAC 2012), dan kadar karbohidrat melalui perhitungan by difference. Hasil analisis karakteristik kimia produk dijadikan acuan untuk menyusun informasi nilai gizi produk. Penyusunan informasi nilai gizi pada label kemasan merujuk pada pedoman pencantuman informasi nilai gizi pada label pangan (BPOM 2011) serta acuan label gizi produk pangan (BPOM 2016). Informasi nilai gizi produk terdiri atas takaran saji, jumlah asupan kalori, serta angka kecukupan gizi (\%AKG).
Karakterisasi fisik wedang tahu instan. Karakteristik fisik produk wedang tahu instan yang terdiri atas komponen tahu lembut instan dan kuah jahe instan dianalisis yang meliputi analisis ukuran partikel (mesin pengayak bergetar), aktivitas air (Aw meter), densitas kamba yaitu dengan memasukkan sampel ke dalam gelas ukur hingga volumenya mencapai $50 \mathrm{~mL}$ kemudian beratnya ditimbang (Pangastuti et al. 2013), laju pembasahan (Park et al. 2001), dan indeks ketidaklarutan yaitu dengan menghitung banyaknya sedimen yang tertinggal setelah larutan disentrifuse (Australian Standard 1994).

Aktivitas antioksidan wedang tahu instan. Metode yang digunakan untuk menguji aktivitas antioksidan produk wedang tahu instan yaitu metode DPPH mengacu pada Adedayo et al. (2010). Sebanyak 0.5 gram sampel kering dimasukkan ke dalam $50 \mathrm{~mL}$ akuades mendidih dan diseduh selama dua menit. Setelah diseduh, sampel disaring menggunakan kertas saring lalu ditepatkan $50 \mathrm{~mL}$. Filtrat sampel yang diperoleh diambil sebanyak $1 \mathrm{~mL}$ dimasukkan ke dalam tabung reaksi lalu ditambahkan $3 \mathrm{~mL}$ etanol dan $2 \mathrm{~mL}$ larutan 2,2-Difenil-1 pikrilhidrazin (DPPH) $0.3 \mathrm{mM}$ dalam etanol. Sampel kemudian divorteks dan didiamkan selama 30 menit dalam ruang gelap sebelum dilakukan pengukuran absorbansi pada panjang gelombang 517 nm. Pembuatan kurva standar menggunakan standar asam askorbat dengan variasi konsentrasi $0,10,20,30$, 40, dan $50 \mathrm{ppm}$.

\section{HASIL DAN PEMBAHASAN}

\section{Respon optimasi formula dan proses rehidrasi}

Berdasarkan analisis batas minimum dan maksimum dari masing-masing variabel bebas, program RSM merekomendasikan 19 kombinasi formula dan proses yang harus dianalisis (Tabel 1). Masing-masing kombinasi dianalisis sebanyak tiga kali ulangan.

Tabel 1. Rancangan dan respon optimasi formula tahu lembut instan

\begin{tabular}{|c|c|c|c|c|c|c|}
\hline \multirow[b]{2}{*}{ Formula } & \multicolumn{3}{|c|}{ Komponen (\%) } & \multicolumn{3}{|c|}{ Respon } \\
\hline & $\begin{array}{c}\text { Sari Kedelai } \\
\text { Bubuk }\end{array}$ & Karaginan & $\begin{array}{l}\text { Rasio Tahu } \\
\text { Lembut : air }\end{array}$ & Kekerasan (gf) & Kelengketan (gf) & Daya Kunyah (gf) \\
\hline 1 & 90 & 10 & 0.25 & 978.4 & 265.15 & 93.62 \\
\hline 2 & 90 & 10 & 0.25 & 950.5 & 239.53 & 110.18 \\
\hline 3 & 90 & 10 & 0.20 & 613.6 & 156.46 & 45.38 \\
\hline 4 & 90 & 10 & 0.17 & 435.55 & 128.5 & 45.1 \\
\hline 5 & 90 & 10 & 0.13 & 291.05 & 80.04 & 28.17 \\
\hline 6 & 90 & 10 & 0.13 & 249.65 & 44.93 & 26.94 \\
\hline 7 & 91.5 & 8.5 & 0.20 & 590.2 & 172.34 & 60.49 \\
\hline 8 & 91.5 & 8.5 & 0.14 & 552.55 & 165.76 & 59.01 \\
\hline 9 & 93 & 7 & 0.25 & 635.75 & 152.58 & 77.63 \\
\hline 10 & 93 & 7 & 0.17 & 271.15 & 77.82 & 40.23 \\
\hline 11 & 93 & 7 & 0.13 & 171 & 29.07 & 18.89 \\
\hline 12 & 93 & 7 & 0.13 & 148.35 & 32.78 & 16.06 \\
\hline 13 & 94.5 & 5.5 & 0.20 & 66.35 & 18.38 & 7.65 \\
\hline 14 & 94.5 & 5.5 & 0.14 & 44.8 & 8.52 & 5.95 \\
\hline 15 & 96 & 4 & 0.25 & 98.6 & 20.8 & 8.67 \\
\hline 16 & 96 & 4 & 0.25 & 106.6 & 22.26 & 9.32 \\
\hline 17 & 96 & 4 & 0.17 & 58.15 & 14.25 & 6.98 \\
\hline 18 & 96 & 4 & 0.13 & 38 & 11.4 & 2.44 \\
\hline 19 & 96 & 4 & 0.13 & 36.55 & 14.62 & 2.63 \\
\hline
\end{tabular}


Respon kekerasan yang dihasilkan dari kombinasi berkisar antara 36.55 hingga 978.40 gf. Model yang terpilih oleh program untuk respon kekerasan adalah linear karena memiliki nilai $\mathrm{R}^{2}$ lebih besar dibandingkan model lain yaitu 0.92. Hasil analisis ANOVA menunjukkan bahwa model yang direkomendasikan tersebut berpengaruh secara signifikan pada respon kekerasan $(\mathrm{p}<0.05)$. Nilai lack of fit menunjukkan nilai $\mathrm{p}<0.05$ sehingga hasilnya pun signifikan. Persamaan RSM untuk optimasi formula dan proses rehidrasi tahu lembut instan terhadap respon kekerasan dapat dilihat pada Tabel 2.

Tabel 2. Persamaan respon kekerasan, kelengketan, dan daya kunyah tahu lembut instan

\begin{tabular}{ll}
\hline \multicolumn{1}{c}{ Parameter } & \multicolumn{1}{c}{ Persamaan } \\
\hline Kekerasan & Kekerasan $=27.03 \mathrm{~A}-1.07 \mathrm{~B}+1722.81 \mathrm{AB}+$ \\
(gf) & $1.10 \mathrm{AC}-26.49 \mathrm{BC}-0.67 \mathrm{AB}(\mathrm{A}-\mathrm{B})$ \\
Kelengketan & Kelengketan $=9.87 \mathrm{~A}-36311.49 \mathrm{~B}+583.69$ \\
(gf) & $\mathrm{AB}+0.30 \mathrm{AC}-7.20 \mathrm{BC}-0.02 \mathrm{AB}(\mathrm{A}-\mathrm{B})$ \\
Daya Kunyah & Daya Kunyah $=-12.44 \mathrm{~A}+300.35 \mathrm{~B}+6.15 \mathrm{AC}$ \\
(gf) & $-147.52 \mathrm{BC}-1.02 \mathrm{AC}^{2}+24.44 \mathrm{BC}^{2}+0.06$ \\
& $\mathrm{AC}^{3}-1.33 \mathrm{BC}^{3}$ \\
\hline
\end{tabular}

Keterangan: $\mathrm{A}=$ Konsentrasi sari kedelai $(\%) ; \mathrm{B}=$ Konsentrasi karaginan $(\%) ; \mathrm{C}=$ Rasio volume air $(\mathrm{b} / \mathrm{v})$

Persamaan tersebut menunjukkan bahwa respon kekerasan akan meningkat berbanding lurus dengan peningkatan konsentrasi sari kedelai bubuk, interaksi antara sari kedelai dan karaginan, serta interaksi antara sari kedelai dan air. Sedangkan peningkatan konsentrasi karaginan dan interaksi antara karaginan dan air dapat menurunkan respon kekerasan tahu lembut ditandai dengan konstanta bernilai negatif. Bahan baku sari kedelai dengan total padatan yang tinggi akan menghasilkan tahu dengan nilai tekstur kekerasan yang tinggi. Peningkatan respon kekerasan juga dipengaruhi adanya interaksi antara sari kedelai dan karaginan. Interaksi antara karaginan dengan protein akan menghasilkan gel strength yang diasosiasikan dengan peningkatan kekerasan pada produk tahu (Li et al. 2015). Rasio volume air berpengaruh negatif pada respon kekerasan tahu lembut instan. Semakin banyak air yang ditambahkan pada produk pangan instan, semakin menurun tekstur kekerasannya. Respon kekerasan secara visual diperlihatkan grafik tiga dimensi pada Gambar 1.

Respon kelengketan yang dihasilkan dari kombinasi berkisar antara 8.52 hingga 256.15 gf. Model yang terpilih oleh program untuk respon kekerasan adalah linear karena memiliki nilai $\mathrm{R}^{2}$ lebih besar dibandingkan model lain yaitu 0.93. Hasil analisis ANOVA menunjukkan bahwa model yang direkomendasikan tersebut berpengaruh secara signifikan pada respon kelengketan $(\mathrm{p}<0.05)$. Nilai lack of fit menunjukkan nilai $\mathrm{p}>0.05$ sehingga hasilnya tidak signifikan. Persamaan RSM untuk optimasi formula dan proses rehidrasi tahu lembut instan terhadap respon kelengketan menunjukkan bahwa respon kelengketan akan meningkat berbanding lurus dengan peningkatan konsentrasi sari kedelai bubuk, interaksi antara sari kedelai dan karaginan, serta interaksi antara sari kedelai dan air. Sedangkan peningkatan konsentrasi karaginan dan interaksi antara karaginan dan air dapat menurunkan respon kelengketan tahu lembut.

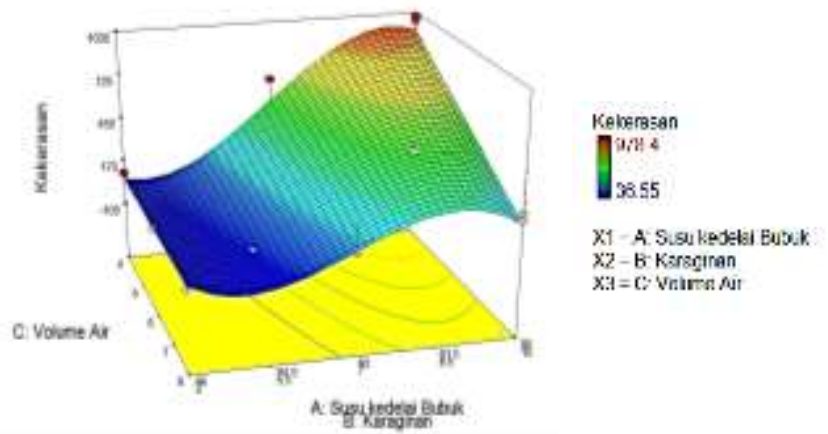

Gambar 1. Respon kekerasan tahu lembut berdasarkan konsentrasi sari kedelai $(A)$, karaginan $(B)$, dan rasio volume air $(\mathrm{C})$

Faktor-faktor yang berpengaruh pada nilai kekerasan tahu akan berpengaruh nyata pula terhadap nilai kelengketan tahu. Menurut Saha et al. (2010), adanya interaksi antara karaginan dengan sari kedelai pada konsentrasi yang tinggi dapat meningkatkan pembentukan ikatan karaginan-protein sehingga tekstur tahu semakin kompak dan daya kohesif nya pun meningkat. Tahu dengan nilai kekerasan dan daya kohesif yang tinggi akan memiliki nilai kelengketan yang tinggi pula. Respon kelengketan secara visual diperlihatkan grafik tiga dimensi pada Gambar 2.

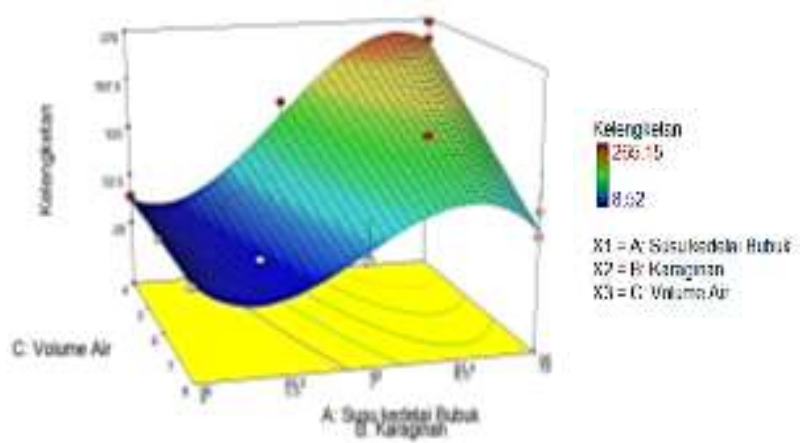

Gambar 2. Respon kelengketan tahu lembut berdasarkan konsentrasi sari kedelai $(A)$, karaginan $(B)$, dan rasio volume air $(\mathrm{C})$

Respon daya kunyah yang dihasilkan dari kombinasi berkisar antara 20.44 hingga 110.18 gf. Model yang terpilih oleh program untuk respon daya kunyah adalah linear karena memiliki nilai $\mathrm{R}^{2}$ lebih besar dibandingkan model lain yaitu 0.87. Hasil analisis ANOVA, menunjukkan bahwa model yang direkomendasikan tersebut berpengaruh secara signifikan pada respon kekerasan $(\mathrm{p}<0.05)$. Nilai lack of fit menunjukkan nilai $\mathrm{p}<0.05$ sehingga hasilnya pun signifikan. Persamaan RSM untuk optimasi formula dan proses rehidrasi tahu lembut instan terhadap respon daya kunyah menunjukkan bahwa respon daya kunyah akan meningkat berbanding lurus dengan peningkatan konsentrasi karaginan, interaksi antara sari kedelai dan air, serta kuadrat interaksi antara karaginan dan air. Sedangkan peningkatan konsentrasi sari kedelai dan interaksi antara sari kedelai 
dan air dapat menurunkan respon kekerasan tahu lembut. Faktor-faktor yang berpengaruh pada nilai kekerasan dan daya kohesif tahu akan berpengaruh nyata pula terhadap nilai daya kunyah tahu. Peningkatan respon daya kunyah terutama dipengaruhi oleh karaginan ditandai dengan konstanta bernilai tinggi yaitu 300.35. Menurut Li et al. (2015), karaginan yang ditambahkan pada pembuatan tahu dapat memengaruhi peningkatan kekerasan secara signifikan. Peningkatan tekstur kekerasan pada tahu akan menye-babkan peningkatan energi yang diperlukan untuk menguyah tahu tersebut hingga dapat ditelan. Respon daya kunyah secara visual diperlihatkan grafik tiga dimensi pada Gambar 3.

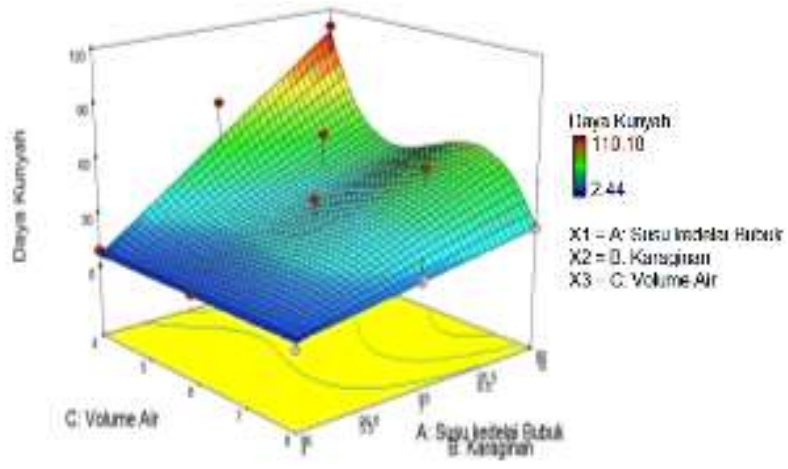

Gambar 3. Respon daya kunyah tahu lembut berdasarkan konsentrasi sari kedelai (A), karaginan (B), dan rasio volume air $(\mathrm{C})$

\section{Formula dan proses rehidrasi optimum tahu lembut instan}

Penetapan target respon didasarkan pada pengamatan visual produk akhir tahu lembut yang dikorelasikan dengan hasil pengukuran tekstur menggunakan Texture Analyzer. Berdasarkan optimasi numerik yang dilakukan, diperoleh Kombinasi optimal tahu lembut instan terpilih oleh program adalah konsentrasi sari kedelai $93.2 \%$, karaginan $6.8 \%$, dan rasio volume serbuk:air 1:8 dengan nilai desirability 1.00. Nilai desirability merupakan nilai fungsi tujuan optimasi yang menunjukkan kemampuan program untuk memenuhi keinginan berdasarkan kriteria yang ditetapkan pada produk akhir. Menurut Nurmiah et al. (2013), nilai desirability mendekati 1 menunjukkan kemampuan program untuk menghasilkan produk yang dikehendaki semakin sempurna.

Formula dan proses rehidrasi tahu lembut instan terpilih selanjutnya diverifikasi untuk mengetahui kemampuan model yang disarankan program dalam memprediksi nilai respon kekerasan, kelengketan dan daya kunyah. Berdasarkan hasil pengukuran aktual tekstur tahu lembut instan dengan Texture Analyzer, diperoleh nilai kekerasan tahu lembut sebesar 154.60 gf, kelengketan sebesar 28.53 gf dan daya kunyah sebesar 16.16 gf. Nilai aktual hasil pengukuran dan nilai prediksi yang dihasilkan program dapat dilihat pada Tabel 3.
Tabel 3. Hasil pengukuran aktual dan niai prediksi respon tekstur tahu lembut optimal

\begin{tabular}{lcccc}
\hline \multicolumn{1}{c}{ Respon } & Aktual & Prediksi & 95\% Cl low & $\begin{array}{c}\text { 95\% Cl } \\
\text { High }\end{array}$ \\
\hline $\begin{array}{l}\text { Kekerasan (gf) } \\
\text { Kelengketan } \\
\text { (gf) }\end{array}$ & 154.60 & 144.73 & 66.57 & 222.90 \\
$\begin{array}{l}\text { Daya kunyah } \\
\text { (gf) }\end{array}$ & 28.53 & 34.71 & 15.21 & 54.22 \\
\hline
\end{tabular}

Nilai aktual yang diperoleh berdasarkan pengukuran masih berada dalam rentang 95\% CI low dan 95\% CI high. CI (Confidence Interval) merupakan rentang yang menunjukkan nilai terendah dan tertinggi dari kisaran prediksi rata-rata hasil pengukuran pada taraf signifikansi 95\% (Montgomery 2001). Kesesuaian antara nilai aktual dan prediksi menunjukkan bahwa model yang digunakan terverifikasi dan cukup konsisten.

\section{Karakteristik fisik wedang tahu instan}

Wedang tahu instan tersusun atas serbuk tahu lembut instan dan kuah jahe instan. Hasil analisis fisik terhadap serbuk tahu lembut instan dan kuah jahe instan dapat dilihat pada Tabel 6 .

Tabel 6. Karakteristik fisik wedang tahu instan

\begin{tabular}{lcc}
\hline \multicolumn{1}{c}{ Parameter } & $\begin{array}{c}\text { Serbuk Tahu } \\
\text { Lembut Instan }\end{array}$ & $\begin{array}{c}\text { Serbuk Kuah } \\
\text { Jahe Instan }\end{array}$ \\
\hline Ukuran partikel (mesh) & 100 & 40 \\
$\mathrm{~A}_{\mathrm{w}}$ & $0.544 \pm 0.006$ & $0.720 \pm 0.001$ \\
Densitas kamba $(\mathrm{g} / \mathrm{mL})$ & $0.555 \pm 0.006$ & $0.653 \pm 0.007$ \\
Laju pembasahan $(\mathrm{g} / \mathrm{s})$ & $0.442 \pm 0.03$ & $0.034 \pm 0.0006$ \\
Indeks ketidaklarutan & $17.67 \pm 0.28$ & $0.5 \pm 0.00$ \\
$(\mathrm{~mL})$ & & \\
\hline
\end{tabular}

Karakteristik fisik produk serbuk dapat memengaruhi proses penyajian maupun penyimpanannya. Ukuran partikel serbuk tahu lembut instan sebesar 100 mesh dan serbuk kuah jahe instan sebesar 40 mesh. Ukuran partikel serbuk tahu lembut instan sesuai dengan kisaran ukuran minuman instan komersial yaitu >80 mesh. Begitu pula dengan ukuran partikel serbuk kuah jahe instan sesuai dengan kisaran ukuran sari jahe instan komersial yaitu berkisar antara 40 hingga 60 mesh (Yuliani dan Kailaku 2009).

Nilai $\mathrm{A}_{\mathrm{w}}$ serbuk tahu lembut instan sebesar 0.544 dan serbuk kuah jahe instan sebesar 0.720. Nilai $A_{w}$ kedua serbuk instan tersebut masih dinilai cukup baik untuk penyimpanan karena berada dalam kisaran $\mathrm{A}_{\mathrm{w}}$ umum untuk serbuk instan yaitu sekitar 0.72 (Kusnandar 2010). Selain itu, serbuk tahu lembut instan dan kuah jahe instan ini akan dikemas dalam kemasan sachet yang diharapkan dapat mempertahankan mutu produk selama penyimpanan. Densitas kamba serbuk tahu lembut instan sebesar $0.555 \mathrm{~g} / \mathrm{mL}$ dan serbuk kuah jahe instan sebesar $0.653 \mathrm{~g} / \mathrm{mL}$. Menurut Rohmah (2012), nilai densitas kamba produk tepung berkisar antara 0.3 hingga 0.8 sehingga nilai densitas kamba serbuk tahu lembut instan dan kuah jahe instan tergolong cukup baik. Laju pembasahan serbuk tahu lembut instan sebesar $0.034 \mathrm{~g} / \mathrm{s}$ dan serbuk kuah jahe instan sebesar $0.442 \mathrm{~g} / \mathrm{s}$. Laju pembasahan menunjukkan seberapa cepat suatu produk basah oleh air. Nilai laju pembasahan yang tinggi 
menunjukkan bahwa serbuk membutuhkan waktu yang lebih singkat untuk menyerap air. Nilai indeks ketidaklarutan serbuk tahu lembut instan sebesar $17.67 \mathrm{~mL}$ dan serbuk kuah jahe instan sebesar $0.5 \mathrm{~mL}$. Indeks ketidaklarutan umumnya digunakan sebagai parameter untuk mengetahui kualitas kelarutan sari bubuk. Nilai indeks ketidaklarutan yang semakin rendah menunjuk-kan semakin baik kualitas kelarutan produk.

\section{Karakteristik kimia dan nilai gizi wedang tahu instan}

Hasil analisis proksimat dan aktivitas antioksidan serbuk wedang tahu instan dapat dilihat pada Tabel 5.

Tabel 5. Karakteristik kimia dan aktivitas antioksidan serbuk wedang tahu instan

\begin{tabular}{lc}
\hline \multicolumn{1}{c}{ Parameter } & Wedang Tahu Instan \\
\hline Kadar air (\%bb) & $4.54 \pm 0.12$ \\
Kadar abu (\%bb) & $5.10 \pm 0.07$ \\
Kadar protein (\%bb) & $29.46 \pm 0.16$ \\
Kadar lemak (\%bb) & $16.04 \pm 0.19$ \\
Kadar karbohidrat (\%bb) & $44.86 \pm 0.16$ \\
Aktivitas antioksidan (ppm AEAC) & $16.16 \pm 0.16$ \\
\hline
\end{tabular}

Berdasarkan analisis yang dilakukan, wedang tahu instan memiliki kadar air 4.54\%, kadar abu 5.10\%, kadar protein $29.46 \%$, kadar lemak $16.04 \%$, dan kadar karbohidrat $44.86 \%$. Kadar air serbuk wedang tahu instan sebesar $4.54 \%$. Menurut Winarno (2008), produk pangan tepung dengan kadar air kurang dari $10 \%$ memiliki $\mathrm{A}_{\mathrm{w}}$ sekitar 0.5. Pada tingkat ini tepung sudah cukup aman dari berbagai reaksi kimia dan biologis yang dapat merusak kestabilan tepung selama penyimpanan.

Kadar abu wedang tahu instan sebesar $5.10 \%$. Nilai kadar abu yang tinggi pada wedang tahu instan dipengaruhi penggunaan koagulan karaginan yang diperoleh dari hasil ekstraksi rumput laut. Rumput laut mengandung mineral tinggi karena dapat menyerap mineral dari lingkungannya (Santoso et al. 2006). Kadar protein wedang tahu instan sebesar $29.46 \%$. Nilai kadar protein yang cukup tinggi ini dipengaruhi penggunaan kedelai sebagai bahan baku. Kedelai diketahui sebagai salah satu bahan pangan nabati dengan kandungan protein yang tinggi. Kadar lemak wedang tahu instan sebesar $16.04 \%$. Lemak pada wedang tahu berasal dari bahan baku kedelai yang digunakan. Kedelai mengandung asam lemak esensial, yaitu asam linoleat serta linolenat. Kadar lemak yang tinggi pada wedang tahu instan juga dipengaruhi penambahan krimer nabati pada komposisinya.

Kadar karbohidrat wedang tahu instan sebesar $44.86 \%$. Karbohidrat pada kedelai berupa karbohidrat kompleks, meliputi sukrosa, pati dan oligosakarida yang larut air yaitu stakiosa dan rafinosa (Wang et al. 2007). Oligosakarida bersifat tidak dapat dicerna dan berperan sebagai prebiotik yang resisten terhadap enzim pencernaan. Wedang tahu instan memiliki aktivitas antioksidan sebesar $16.16 \pm 0.16$ ppm AEAC. Tahu lembut instan memiliki aktivitas antioksidan sebesar $7.46 \pm 0.16 \mathrm{ppm}$ AEAC dan kuah jahe instan sebesar $26.04 \pm 0.23$ ppm
AEAC. Kedelai pada tahu lembut mengandung senyawa bioaktif isoflavon yang berperan sebagai antioksidan. Kedelai diketahui mengandung beberapa jenis isoflavon yaitu daidzein, glycitein dan genistein yang memiliki daya estrogenik, antifungal dan antioksidan (Setchell et al. 2003). Jahe sebagai bahan baku kuah jahe instan juga dikenal menghasilkan aktivitas antioksidan yang tinggi. Menurut Purnomo et al. (2010), senyawa bioaktif non volatil fenol seperti gingerol dan shogaol yang terdapat pada jahe terbukti memiliki kemampuan sebagai antioksidan. Gingerol dan shogaol mampu bertindak sebagai antioksidan primer terhadap radikal bebas.

Informasi nilai gizi adalah daftar kandungan zat gizi pada label produk pangan sesuai dengan format yang dibakukan (BPOM 2011). Informasi nilai gizi pada label pangan mencakup takaran saji, zat gizi yang terkandung, energi yang disumbangkan serta presentase angka kecukupan gizi (\%AKG). Jumlah takaran saji wedang tahu instan sebesar $38 \mathrm{~g}$ mengacu pada takaran saji wedang tahu tradisional di pasaran. Konsumsi wedang tahu instan dengan takaran saji tersebut dapat menghasilkan energi total sebesar 175.78 kkal. Energi total tersebut diperoleh dari energi per sajian yang disumbangkan protein sebesar $46.90 \mathrm{kkal} / 38 \mathrm{~g}$ (AKG $19.55 \%$ ), lemak sebesar $57.46 \mathrm{kkal} / 38 \mathrm{~g}$ (AKG 9.52\%), dan karbohidrat sebesar $71.42 \mathrm{kkal} / 38 \mathrm{~g}$ (AKG 5.50\%). Konsep label informasi nilai gizi wedang tahu instan dapat dilihat pada Gambar 4.

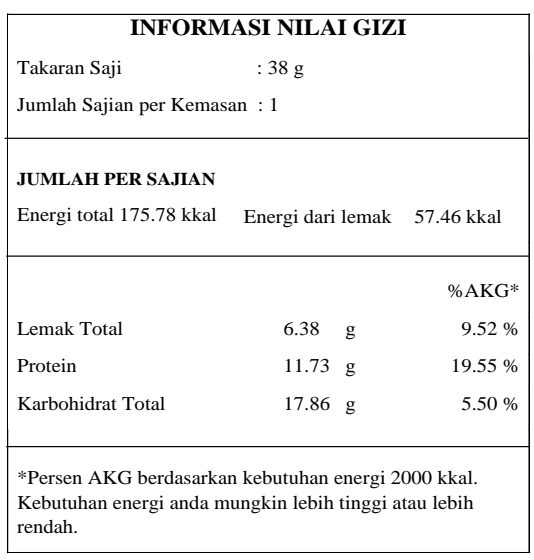

Gambar 4.Konsep label informasi nilai gizi kemasan wedang tahu instan

\section{Karakteristik sensori wedang tahu instan}

Karakteristik penerimaan wedang tahu instan dan wedang tahu tradisional dapat dilihat pada Tabel 4.

Tabel 4. Karakteristik sensori wedang tahu instan optimal dan wedang tahu tradisional berdasarkan rating kesukaan panelis

\begin{tabular}{lcc}
\hline \multirow{2}{*}{ Parameter Sensori ${ }^{1}$} & \multicolumn{2}{c}{ Wedang Tahu } \\
\cline { 2 - 3 } & Instan & Tradisional $^{2}$ \\
\hline Warna & $5.47 \pm 1.11^{\mathrm{a}}$ & $4.54 \pm 1.22^{\mathrm{b}}$ \\
Aroma & $4.48 \pm 1.17^{\mathrm{a}}$ & $5.08 \pm 1.04^{\mathrm{b}}$ \\
Rasa & $5.50 \pm 1.06^{\mathrm{a}}$ & $4.31 \pm 1.45^{\mathrm{b}}$ \\
Tekstur & $6.10 \pm 0.80^{\mathrm{a}}$ & $4.21 \pm 1.53^{\mathrm{b}}$ \\
Over all & $5.67 \pm 0.86^{\mathrm{a}}$ & $4.61 \pm 1.21^{\mathrm{b}}$ \\
\hline
\end{tabular}

Keterangan: ${ }^{1}$ Skala hedonik rentang 1 (sangat tidak suka) hingga 7 (sangat suka). ${ }^{2}$ Angka pada kolom yang sama diikuti oleh huruf yang berbeda, berbeda nyata $\mathrm{p}<0.05$ 
Rata-rata panelis lebih menyukai wedang tahu instan dibandingkan wedang tahu tradisional pada respon warna, rasa, tekstur, maupun keseluruhan. Nilai tingkat kesukaan terhadap warna wedang tahu instan adalah $5.47 \pm 1.11$ lebih tinggi dibandingkan wedang tahu tradisonal yaitu $4.54 \pm 1.22$. Atribut warna pada wedang tahu terutama dipengaruhi oleh kuah jahe. Kuah jahe pada wedang tahu tradisional memiliki intensitas warna yang jauh lebih gelap dibandingkan wedang tahu instan. Perbedaan intensitas warna tersebut dipengaruhi perbedaan konsentrasi gula merah yang digunakan. Konsentrasi gula merah yang digunakan pada penelitian ini didasarkan pada formula optimal yang diperoleh pada penelitian terkait sebelumnya (Wardiani 2015).

Nilai tingkat kesukaan terhadap aroma wedang tahu instan adalah $4.48 \pm 1.17$ lebih rendah dibandingkan wedang tahu tradisonal yaitu $5.08 \pm 1.04$. Aroma kuah jahe dipengaruhi oleh senyawa volatil (minyak atsiri) pada jahe. Semakin tinggi kandungan minyak atsiri akan menghasilkan intensitas aroma yang semakin kuat. Kuah jahe pada wedang tahu instan dibuat melalui metode kristalisasi menggunakan proses pemanasan hingga terbentuk serbuk. Komponen minyak atsiri pada jahe sebagian besar hilang selama proses pemanasan sehingga aroma nya pun berkurang. Nilai tingkat kesukaan terhadap rasa wedang tahu instan adalah $5.50 \pm 1.06$ lebih tinggi dibandingkan wedang tahu tradisional yaitu $4.31 \pm 1.45$. Panelis cenderung kurang menyukai rasa tahu lembut pada wedang tahu tradisional akibat rasa pahit yang dihasilkan. Rasa pahit yang muncul diakibatkan oleh kalsium sulfat yang digunakan sebagai bahan penggumpal pada pembuatan tahu lembut tradisional.

Nilai tingkat kesukaan terhadap tekstur wedang tahu instan adalah $6.10 \pm 0.80$ lebih tinggi dibandingkan wedang tahu tradisional yaitu $4.21 \pm 1.53$. Tekstur tahu lembut pada wedang tahu tradisional cenderung lunak dan mudah hancur, sedangkan tahu lembut pada wedang tahu instan lebih lembut dan kokoh. Tahu lembut pada wedang tahu instan menggunakan karaginan yang diketahui dapat meningkatkan kekerasan secara signifikan (Li et al. 2015). Nilai tingkat kesukaan terhadap wedang tahu instan secara keseluruhan adalah $5.67 \pm 0.86$ yang berarti penerimaan keseluruhan wedang tahu instan mencapai agak suka hingga suka oleh konsumen. Nilai tersebut lebih tinggi dibandingkan tingkat kesukaan secara keseluruhan terhadap wedang tahu tradisional yaitu $4.61 \pm 1.21$.

\section{KESIMPULAN}

Berdasarkan optimasi formula dan proses rehidrasi tahu lembut instan menggunakan metode Response Surface Methodology (RSM) dengan variabel bebas berupa konsentrasi sari kedelai, karaginan dan rasio volume air, diperoleh kombinasi konsentrasi sari kedelai $93.2 \%$, karaginan $6.8 \%$, dan rasio volume serbuk:air 1:8 dengan nilai desirability 1.00. Formula tersebut menghasilkan respon nilai kekerasan sebesar 154.60 gf, kelengketan sebesar 28.53 gf dan daya kunyah sebesar 16.16 gf. Serbuk tahu lembut instan memilki ukuran partikel 100 mesh, $\mathrm{A}_{\mathrm{w}}$ 0.544, densitas kamba 0.555 $\mathrm{g} / \mathrm{mL}$, laju pembasahan $0.442 \mathrm{~g} / \mathrm{s}$ dan indeks kelarutan $17.67 \mathrm{~mL}$, sedangkan serbuk kuah jahe instan memiliki ukuran partikel 40 mesh, $A_{w} 0.720$, densitas kamba $0.653 \mathrm{~g} / \mathrm{mL}$, laju pembasahan $0.034 \mathrm{~g} / \mathrm{s}$ dan indeks kelarutan $0.5 \mathrm{~mL}$. Konsumsi wedang tahu instan dengan takaran saji $38 \mathrm{~g}$ dapat menghasilkan energi sebesar $175.78 \mathrm{kkal}$, protein $19.55 \%$ AKG, lemak 9.52\% AKG, dan karbohidrat $5.50 \%$ AKG. Wedang tahu instan memiliki aktivitas antioksidan sebesar $16.16 \mathrm{ppm}$ AEAC. Warna, rasa, tekstur dan keseluruhan (overall) wedang tahu instan lebih disukai panelis dibandingkan wedang tahu tradisional secara signifikan $(\mathrm{p}<0.05)$.

\section{DAFTAR PUSTAKA}

Adedayo BC, Oboh G, Akindahunsi AA. 2010. Changes in the total phenol content and antioxidant properties of pepperfruit (Dennetia tripetala) with ripening. Afr J Food Sci 4(6): 403-409.

[AOAC] Association of Official Analytical Chemist. 2012. Official Method of Analysis. Washington DC (US): AOAC International.

[BPOM] Badan Pengawas Obat dan Makanan. 2011. Pedoman Pencantuman Informasi Nilai Gizi Pada Label Pangan. Jakarta (ID): Badan Pengawas Obat dan Makanan.

[BPOM] Badan Pengawas Obat dan Makanan. 2016. Acuan Label Gizi Produk Pangan. Jakarta (ID): Badan Pengawas Obat dan Makanan.

[BSN] Badan Standardisasi Nasional. 2006. Petunjuk Pengujian Organoleptik dan atau Sensori. SNI 012346-2006. Jakarta (ID): Badan Standardisasi Nasional.

Campo LV, Kawano DF, Carvalho JI. 2009. Carrageenans: biological properties, chemical modifications and structural analysis. Carbohyd Polym 77: 167180. DOI: 10.1016/j.carbpol.2009. 01.020.

Cornell JA. 2011. A Primer on Experiments with Mixtures. New Jersey (US): J. Wiley. DOI: 10.10 02/9780470907443.

Indrastuti NA. 2015. Optimasi Penggunaan Kalsium Sulfat dan Karaginan pada Pembuatan Tahu Lembut [Skripsi]. Bogor (ID): Institut Pertanian Bogor.

Kao FJ, Su NW, Lee MH. 2003. Effect of calcium sulfate consentration in soy milk on the microstructure of firm tofu and protein constitution in tofu whey. J Agric Food Chem 66: 159-165.

Kusnandar F. 2010. Komponen Makro Kimia Pangan. Jakarta (ID): Dian Rakyat.

Li M, Fusheng C, Bao Y, Shaojuan L, Hongshun Y, Kunlun L, Guanhao B, Caili F, Yun D. 2015. Preparation of organic tofu using organic compatible magnesium chloride incorporated with polysaccharide coagulants. Food Chem 167: 168-174. DOI: 10.1016/j.foodchem.2014.06.102. 
Montgomery DC. 2001. Design and Analysis of Experimental. New York (US): J. Wiley

Mullin WJ, Butler M, Poysa V, Woodrow L. 2001. An interlaboratory test of a procedure to assess soybean quality for soymilk and tofu production. Food Res Int 34: 669-677. DOI: 10.1016/S0963-9969(01)00 $087-4$.

Nurmiah S, Rizal S, Sukarno, Peranginangin R, Budi N. 2013. Aplikasi Response Surface Methodology (RSM) pada optimalisasi kondisi proses pengolahan Alkali Treated Cottonii (ATC). J Teknol Perikanan Kelautan 8(1): 9-22. DOI: 10.15578/jpbkp.v8i1.49.

Obatolu VA. 2007. Effect of different coagulants on rendemen and quality of tofu from soymilk. J EuR Food Res Tech 226: 427-467. DOI: 10.1007/ s00217-006-0558-8.

Pangastuti HA, Affandi DR, Ishartani D. 2013. Karakterisasi sifat fisik dan kimia tepung kacang merah dengan beberapa perlakuan pendahuluan. J Teknosains Pangan 2(1): 20-29.

Park DJ, Imm JY, Ku KH. 2001. Improve dispersibility of green tea powder by microparticulation and formulation. J Food Sci 66(6): 793-796. DOI: 10.11 11/j.1365-2621.2001.tb15174.x.

Purnomo H, Jaya F, Widjanarko SB. 2010. The effect of time and type of thermal processing on ginger (Zingiber Officiale Roscoe) rhizome antioxidant compounds and its quality. Int Food Res J. 17: 335347.

Rifkowaty EE, Martanto. 2016. Minuman fungsional serbuk instan jahe dengan variasi penambahan bawang mekah sebagai pewarna alami. J Teknol Pertanian Lampung 4(4): 315-324.

Rohmah M. 2012. Karakterisasi sifat fisikokimia tepung dan pati pisang kapas (Musa comiculata). J Teknol Pertanian 8(1): 20-24.
Saha D, Auvendu B, Bhattacarya S. 2010. Hydrocolloids as thickening and gelling agents in food: a critical review. J Food Sci Technol 47(6): 587-597. DOI: 10.1007/s13197-010-0162-6.

Santoso J, Gunji S, Yoshie Y, Suzuki T. 2006. Mineral content of Indonesian seaweed and mineral solubility affected by basic cooking. Food Sci Technol Res 12(1): 59-66. DOI: 10.3136/fstr.12.59.

Setchell K, Brown M, Desai PB, Nechimias LZ, Wolfe B, Jakate AS, Heubi JE. 2003. Bioavalibility, disposition and dose-response effects of soy isoflavones when consumed by healthy women at physiologically typical dietary intake. J Nutr 133: 1027-1035. DOI: 10.1093/jn/133.4.1027.

Stoilova I, Krastanov A, Stoyanova A, Denev P, gargova S. 2007. Antioxidant activity of a ginger extract. Food Chem 102: 764-770. DOI: 10.1016/ j.foodchem.2006.06.023.

Wang Q, Leqin K, Dongmei Y, Bili B, Jianmei J, Tiejin Y. 2007. Change in oligosaccharides during processing of soybean sheet. Asia Pacific J Clin Nutr 16(1): 89-94.

Wardiani LI. 2015. Optimasi Formula Kuah Jahe pada Wedang Tahu Berdasarkan Karakteristik Sensori dan Aktivitas Antioksidan [Skripsi]. Bogor (ID): Institut Pertanian Bogor.

Winarno FG. 2008. Kimia Pangan dan Gizi. Bogor (ID): M. Brio Pr.

Winarsi H. 2010. Protein Kedelai dan Kecambah Manfaat bagi Kesehatan. Yogyakarta (ID): Kanisius.

Yuliani S, Kailaku SI. 2009. Pengembangan produk jahe kering dalam berbagai jenis industri. Bul Teknol Pascapanen Pert 5(1): 61-68.

JMP-05-18-17-Naskah diterima untuk ditelaah pada 18 Mei 2018. Revisi makalah disetujui untuk dipublikasi pada 27 September 2019. Versi Online: http://journal.ipb.ac.id/index.php/jmpi 